throughout the EEA, with mutual recognition of professional qualifications; capital movements to be free with some restrictions on investments; EFTA countries not to be bound by the Common Agricultural Policy (CAP) or Common Fisheries Policy (CFP).

The EEA-EFTA states have established a Surveillance Authority and a Court to ensure implementation of the Agreement among the EFTA-EEA states. Political direction is given by the EEA Council which meets twice a year at ministerial level, while ongoing operation of the Agreement is overseen by the EEA Joint Committee. Legislative power remains with national governments and parliaments.

EFTA has formal relations with several other states. Free trade agreements have been signed with Turkey (1991), Israel and Czechoslovakia (1992, with protocols on succession with the Czech Republic and Slovakia in 1993), Poland and Romania (1992), Bulgaria and Hungary (1993), Estonia, Latvia, Lithuania and Slovenia (1995), Morocco (1997), the Palestine Liberation Organization on behalf of the Palestinian Authority (1998), the former Yugoslav Republic of Macedonia and Mexico (2000), Jordan and Croatia (2001), Singapore (2002), Chile (2003), Lebanon and Tunisia (2004), South Korea (2005), the Southern African Customs Union (2006), Egypt (2007), Canada and Colombia (2008), Albania, the Gulf Co-operation Council and Serbia (2009), Peru and Ukraine (2010), Hong Kong and Montenegro (2011), Bosnia and Herzegovina and Central American States (Costa Rica and Panama) (2013), Central American States (Guatemala) (2015), and Georgia and the Philippines (2016). Agreements with the countries that have joined the European Union in the meantime have been replaced by the relevant arrangements between the EFTA states and the EU. Negotiations on free trade agreements are ongoing with Algeria (although negotiations were on hold as at Feb. 2017), Central American States (Honduras) (also on hold as at Feb. 2017), Ecuador, India, Indonesia, Malaysia, Russia, Belarus and Kazakhstan (although as at Feb. 2017 negotiations with these three countries were on hold), Thailand (also on hold as at Feb. 2017) and Vietnam. There are currently Joint Declarations on Co-operation with Mercosur (2000), Mongolia (2007), Mauritius (2009), Pakistan (2012) and Myanmar (2013).

Organization. The operation of the free trade area among the EFTA states is the responsibility of the EFTA Council which meets regularly at ambassadorial level in Geneva. The Council is assisted by a Secretariat and standing committees. Each EFTA country holds the chairmanship of the Council for six months. For EEA matters there is a separate committee structure.

Brussels Office (EEA matters, press and information): 12-16 Rue Joseph II, B-1000 Brussels, Belgium.

Headquarters: 9-11 rue de Varembé, CH-1211 Geneva 20, Switzerland.

Website: http://www.efta.int

Email: mail.gva@efta.int

Secretary-General: Kristinn F. Árnason (Iceland).

Publications. Convention Establishing the European Free Trade Association.EFTA Annual Report (online only)._EFTA Factsheets. - EFTA Bulletin.This is EFTA (annual).-EFTA Commemorative Publications.-EEA Supplements. EFTA Study on Certification and Marks in Europe. 2008.EFTA/EU Statistical Cooperation Handbook. 2011.

\section{European Space Agency (ESA)}

History. Established in 1975, replacing the European Space Research Organization (ESRO) and the European Launcher Development Organization (ELDO).
Members. Austria, Belgium, Czech Republic, Denmark, Estonia, Finland, France, Germany, Greece, Hungary, Ireland, Italy, Luxembourg, the Netherlands, Norway, Poland, Portugal, Romania, Spain, Sweden, Switzerland, United Kingdom. Canada takes part in some projects under a co-operation agreement.

Activities. ESA is the intergovernmental agency in Europe responsible for the exploitation of space science, research and technology for exclusively peaceful purposes. Its aim is to define and put into effect a long-term European space policy that allows Europe to remain competitive in the field of space technology. It has a policy of co-operation with various partners on the basis that pooling resources and sharing work will boost the effectiveness of its programmes. Its space plan covers the fields of science, Earth observation, telecommunications, navigation, space segment technologies, ground infrastructures, space transport systems and microgravity research.

Headquarters: 8-10 rue Mario Nikis, 75738 Paris Cedex 15,

France.

Website: http://www.esa.int

Director-General: Johann-Dietrich Woerner (Germany).

\section{CERN - The European Organization for Nuclear Research}

Founded in 1954, CERN is the world's leading particle physics research centre. By studying the behaviour of nature's fundamental particles, CERN aims to find out what our Universe is made of and how it works. CERN's biggest accelerator, the Large Hadron Collider (LHC), became operational in Sept. 2008. One of the beneficial byproducts of CERN activity is the Worldwide Web, developed at CERN to give particle physicists easy access to shared data. One of Europe's first joint ventures, CERN now has a membership of 22 member states: Austria, Belgium, Bulgaria, Czech Republic, Denmark, Finland, France, Germany, Greece, Hungary, Israel, Italy, the Netherlands, Norway, Poland, Portugal, Romania, Slovak Republic, Spain, Sweden, Switzerland, United Kingdom. Some 12,000 scientists, half of the world's particle physicists, use CERN's facilities. They represent 600 institutions and universities and 120 nationalities.

Address: CH-1211 Geneva 23, Switzerland.

Website: http://home.cern

Email: cern.reception@cern.ch

Director-General: Fabiola Gianotti (Italy).

\section{Central European Initiative (CEI)}

In Nov. 1989 Austria, Hungary, Italy and the then Yugoslavia met on Italy's initiative to form an economic and political cooperation group in the region.

Members. Albania, Austria, Belarus, Bosnia and Herzegovina, Bulgaria, Croatia, Czech Republic, Hungary, Italy, Macedonia, Moldova, Montenegro, Poland, Romania, Serbia, Slovakia, Slovenia, Ukraine.

Address: Executive Secretariat, Via Genova 9, 34132 Trieste, Italy.

Website: http://www.cei.int

Email: cei@cei.int

Secretary General: Giovanni Caracciolo di Vietri (Italy). 